AndRZEJ MoROZ

\title{
Apozycje luźne a wtrącenia zależne formalnie
}

Słowa klucze: składnia formalna, apozycja, wtrącenie, wyrażenie parentetyczne

0.1. Grupy apozycyjne stanowiły przedmiot szczegółowych badań K. Kallas (1980). Wyróżniła ona dwa ich podstawowe typy - konstrukcje ścisłe i luźne. Zasadniczą cechą służącą dyferencjacji obu klas jest obecność graficznych sygnałów izolacji, por.:

(1) Rekin-pożeracz sieje grozę.

(2) Pan Stanisław - miłośnik i wytrawny znawca Krakowa-jeszcze raz zacząt się uczyć.

Za strukturę apozycyjną uznaje się ciąg dwuczłonowy, którego składnikami są podstawa i apozycja (Kallas 1980: 90). W przykładzie (1) komponentem apozycyjnym jest wyrażenie pożeracz, które nie jest oddzielone graficznie ani od podstawy rekin (łącznik nie jest uznawany za znak izolacji), ani od pozostałej części zdania sieje grozę. Inaczej jest w przykładzie (2), gdzie apozycja podlega dwustronnej delimitacji. Jeden znak odizolowania znajduje się od strony wyrażenia podstawowego (Pan Stanisław), drugi zaś od strony ciągu jeszcze raz zacząt się uczyć. Dostrzeżone właściwości potwierdzają wobec tego zasadność wyróżnienia apozycji luźnych (dwustronnie izo- 
lowanych) oraz ścisłych (nieodizolowanych bądź izolowanych jednostronnie). Warto dodać, że w klasie pierwszej znalazły się ciągi, w których zamykający znak izolacji graficznej jest zastępowany kropką, jak również wyrażenia, w których luźnym komponentem jest podstawa, nie zaś apozycja. W drugim z podanych wypadków antepozycyjny znak izolacji - w sytuacji, gdy struktura ta inicjuje ciąg zdaniowy - może mieć realizację zerową ${ }^{1}$ (Kallas 1980: 25-33), por.:

(3) To, co znalazło się na drugiej liście, otrzymuje różę, symbol miłości i uznania.

(4) Pewna dama, aktorka wybrała się do teatru.

Analiza powyższych przykładów prowadzi do przekonania, że ciągi dwustronnie izolowane można interpretować jako struktury wtrącone. Rozstrzygnięcie takie potwierdza K. Kallas (1980: 30), podkreślając, że „człon dwustronnie odizolowany to człon parentetyczny”. Jeżeli tym samym powiążemy dwie hipotezy: (a) apozycja luźna jest dwustronnie izolowana, (b) człon dwustronnie izolowany to człon parentetyczny; to należy uznać fakt, że z definicji wszystkie apozycje luźne są strukturami wtrąconymi.

Powyższe spostrzeżenia uprawniają do sformułowania zasadniczych tez prowadzonych tu obserwacji. Przede wszystkim rozważaniu będzie podlegał problem miejsca luźnych grup apozycyjnych wśród różnych wtrąceń współczesnej polszczyzny, zwłaszcza wtrąceń zależnych formalnie (niewłaściwych). Po drugie, wychodząc z założenia, że struktury apozycyjne są konstrukcjami składającymi się z dwóch rzeczowników, warto poddać obserwacji zbudowane analogicznie ciągi nierzeczownikowe. Wreszcie wskazane jest ustalenie, jakie właściwości można przypisać obiektom zaliczanym do różnych zbiorów wtrąceń. $W$ tym zakresie obserwacji zostaną poddane przede wszystkim formalnosyntaktyczne cechy struktur wtrąconych.

0.2. Punktem odniesienia dla prowadzonych rozważań będzie definicja wtrącenia, jak również klasyfikacja obiektów wyznaczonych tym pojęciem (zob. Moroz 2010). Przyjmuję mianowicie, że wtrącenie jest dowolnym co

1 Autorka dopuszcza również stosowanie w apozycjach luźnych nieparzystych znaków odizolowania, np. łączenie myślnika z przecinkiem czy dwukropkiem, por. Kallas 1980: 29-30. 
najmniej jednosegmentalnym wyrażeniem językowym, będącym częścią zinterpretowanego składniowo wypowiedzenia, izolowanym dwustronnie pauzami artykulacyjnymi, których graficznym odpowiednikiem są znaki interpunkcyjne, oraz stanowiącym redukowalny komponent ciągu syntaktycznego, w którym występuje. Uznaję jednocześnie, że tak wyróżniane obiekty mogą pozostawać w związkach zależności formalnej ze ściśle określonym komponentem całostki, w której się znajdują - stanowią one wówczas wtrącenia niewłaściwe - bądź też nie wykazywać powiązań strukturalnych z żadnym składnikiem terminalnym takiego ciągu - są one wtedy wtrąceniami właściwymi.

Tak zdefiniowane obiekty językowe podlegają dalszym szczegółowym podziałom. Przede wszystkim można wyodrębnić cztery klasy wtrąceń niewłaściwych: (a) wtrącenia równoważne dystrybucyjnie określonemu składnikowi ciągu głównego oraz ustabilizowane pod względem szyku - Kupiłem samochód (starego grata); (b) wtrącenia równoważne dystrybucyjnie określonemu składnikowi ciągu głównego oraz nieustabilizowane pod względem szyku - Wczoraj go widziałem na ulicy, ojca Marysi.; (c) wtrącenia współskładnikowe - Pies (lub kot) mógt zrzucić ten obrazek.; (d) wtrącenia niewspółskładnikowe - Marzy mi się obiad (bardzo wykwintny). W opozycji do nich pozostają dwie klasy wtrąceń właściwych: (e) wtrącenia samodzielne składniowo - Piękny samochód (niestety nie każdy mógł sobie na niego pozwolić) stał przed wejściem do budynku. - oraz (f) wtrącenia niesamodzielne składniowo - Każdy (jak mniemam) chciat się tam dostać.

1. Z obserwacji K. Kallas (1980) wypływa wniosek, że pomiędzy apozycją luźną a członem wtrąconym (parentetycznym) zachodzi relacja tożsamości (por. § 0.1.), innymi słowy, każdy człon dwustronnie izolowany w grupie apozycyjnej może być uznany za wyrażenie wtrącone. Tak sformułowana hipoteza wywołuje jednak pewną liczbę problemów szczegółowych. Przede wszystkim konieczne jest ustalenie, do jakiego typu struktur wtrąconych należy zaliczyć takie realizacje. Po drugie, warto rozważyć tezę o parentetycznym charakterze podstawy w grupie apozycyjnej.

1.1. K. Kallas (1980: 57-83) podaje różne przykłady apozycji luźnych. Jest natomiast rzeczą znamienną, że kwalifikują się one do jednej z dwóch typów struktur wtrąconych - wtrąceń niewłaściwych równoważnych dystrybucyj- 
nie składnikowi struktury głównej i ustabilizowanych pod względem szyku oraz wtrąceń właściwych niesamodzielnych składniowo, por.:

(5) Bohaterka sztuki, młoda lekarka, popetniła samobójstwo.

(6) Trafit się pan na stanowisku, buchalter z Warszawy.

(7) Zwiedzat Warszawe, stolica Polski.

(8) Pójdę do Janka (kierownik placówki) i zapytam go. (Grochowski 1983: 252)

Zauważmy, że przykłady (5) i (6) różnią się od (7) i (8). W pierwszej parze człon izolowany jest równoważny syntaktycznie podstawie apozycji - może ją zastąpić w niezmienionej strukturze zdania. Inaczej jest $\mathrm{w}$ realizacjach (7) i (8), gdzie wyrażenia stolica Polski oraz kierownik placówki nie są równoważne członom Warszawę oraz Janka. Zgadzam się tym samym w pełni z tezą K. Kallas (1980: 71-72), że „nawiasowe wtrącenia nie są w ogóle akomodowane, o ile stoją w mianowniku” oraz ,znak izolacji uniemożliwia narzucenie wartości mianownika podrzędnikowi”, por.:

(5a) Młoda lekarka popetniła samobójstwo.

(7a) * Zwiedzat stolica Polski.

1.2. Inaczej należy interpretować apozycje luźne, których podstawienie za człon ciągu głównego - za podstawę - jest w znacznej mierze utrudnione, przede wszystkim z uwagi na różnice w zakresie wartości kategorii rodzaju bądź liczby, por.:

(9) Cała nasza trójka, Piotruś, Leszek i Wojtuś, czekała cierpliwie.

(10) Olimp, siedziba bogów, otoczony byt kultem.

(10a) * Siedziba bogów otoczony byt kultem.

(11) My, brać aktorska, zawsze mieliśmy wspólny język.

(11a) * Brać aktorska zawsze mieliśmy wspólny język.

Izolowane w powyższych strukturach człony - Piotruś, Leszek i Wojtuś w (9); siedziba bogów w (10) i brać aktorska w (11) - różnią się wartościami kategorii rodzaju bądź liczby od antepozycyjnych podstaw apozycji (por. Kallas 1978: 14). Tym samym zestawiane elementy zachowują jedynie toż- 
samość wartości przypadka. Cechy te sprawiają, że powyższe wyrażenia wtrącone należy uznać za komponenty zależne składniowo, ale nierównoważne dystrybucyjnie żadnemu członowi struktury głównej. Obserwowalna w tym wypadku transmisja przypadka ze strony nadrzędnika grupy apozycyjnej pozwala zaliczyć takie realizacje do klasy $\mathrm{C}$ wyodrębnionych wcześniej wtrąceń - ciągów zależnych formalnie oraz dołączanych do struktury głównej dzięki konotacji współskładnika. Argumentację za taką decyzją badawczą przytoczę w dalszej części tekstu (zob. § 2.4.).

1.3. Drugim problemem wymagającym szczegółowych analiz jest antepozycja członu wtrąconego względem składnika wyrażenia zdaniowego. K. Kallas (1980: 29) przyjmuje, że w przykładach:

(4) Pewna dama, aktorka wybrała się do teatru.

(12) ?Ten mazgaj, Basia znowu płakała.

członem dwustronnie izolowanym jest podstawa apozycji - komponent występujący w antepozycji względem rzeczowników aktorka lub Basia. Tym samym autorka odrzuca możliwość uznania takich realizacji za ścisłe grupy apozycyjne. Wydaje się jednak, że na takie wyrażenia warto spojrzeć w jeszcze inny sposób. Można je bowiem uznać za konstrukcje wątpliwe (błędne interpunkcyjnie), z uwagi na brak jednego ze znaków izolacji graficznej (postpozycyjnego), por.:

(4a) Pewna dama, aktorka, wybrała sie do teatru.

(12a) Ten mazgaj, Basia, znowu płakała.

Tym samym członem wtrąconym (parentetycznym) byłaby apozycja, nie zaś podstawa. Za takim rozstrzygnięciem przemawia kilka argumentów. Prawdą jest, że człon wtrącony jest dwustronnie izolowany, jak również to, że lokalizacja takiej całostki w postpozycji bądź antepozycji zdania skutkuje zerową realizacją jednego ze znaków interpunkcyjnych. Zauważmy jednak, że dodanie w przykładzie (4) w antepozycji członu pewna dama podrzędnika czasownika wybrała się prowadzi do powstania konstrukcji wątpliwej interpunkcyjnie, por.: 
(4b) ?Wczoraj, pewna dama, aktorka wybrała się do teatru.

Przyczyną takiego stanu rzeczy jest identyfikowana w wypadku charakteryzowanych w tym miejscu wtrąceń regresywność wchodzenia w stosunki syntaktyczne. Człon dopowiedziany występuje po komponencie, do którego się odnosi. Rozstrzygnięcie takie nie rozwiązuje jednak problemu grupy ten mazgaj, Basia, płakała, ale - jak można przypuszczać - do takich konstrukcji znajdują zastosowanie orzeczenia wydawnictw poprawnościowych, przyjmujące, że w wypadku rzeczowników odnoszących się zarówno do kobiet, jak i mężczyzn o kształcie orzeczenia decyduje płeć osoby, por. Jadacka 2005: $144^{2}$. Tym samym wystąpienie takich jednostek bez leksykalnego wykładnika pozwalającego na jednoznaczne zidentyfikowanie płci referenta prowadzi do uzgodnienia selektywnej wartości kategorii rodzaju rzeczowników mazgaj w (12) czy użytkownik w (13) z wartościami modulującymi tych kategorii w czasownikach płakać w (12) i napisać w (13). Inaczej jest jednak w sytuacji, gdy przytoczone wyrażenia nominalne są uzupełnione odpowiednim wykładnikiem pozwalającym na zidentyfikowanie płci osoby. Forma finitywna przyjmuje wówczas wartość kategorii rodzaju zgodną z rodzajem tegoż wykładnika, por.:

(13) Użytkownik napisat: spróbuj maści Lipobasa.

(13a) Użytkownik, Kasia, napisała: spróbuj maści Lipobasa.

(13b) ?Użytkownik, Kasia, napisat: spróbuj maści Lipobasa.

Nowy słownik poprawnej polszczyzny przyjmuje również, że dodatkowe (uzupełniające) określenia podmiotu nie mają wpływu na postać orzeczenia, choć dostrzega odstępstwo od tej zasady w sytuacji, kiedy „określenie wskazuje jednoznacznie płeć osoby wykonującej czynność - orzeczenie ma wtedy formę gramatyczną uwzględniającą ten fakt, np. Nasz znakomity profesor, Helena Narbutt, jest zafascynowana Cyceronem (nie:... *jest zafascynowany...)" (NSPP 2000: 1784).

${ }^{2}$ W wydawnictwach normatywnych można znaleźć również rozstrzygnięcia, że w takim wypadku należy dążyć do utrzymania zgody formalnogramatycznej, a jeszcze lepiej unikać takich realizacji zgodnie z zasadą „lepiej zapobiegać niż leczyć”, por. Buttler (1986: 330-331), Jadacka (2005: 148), NSPP (2000: 1784). 
Przyjęcie powyższych argumentów pozwala tym samym zaakceptować przykład (12a), co prowadzi do uznania zdań (4), (4a), (12) i (12a) bądź za apozycje ścisłe - z takiej interpretacji rezygnuje K. Kallas (1980: 29) - bądź też luźne z dwustronną izolacją członu postpozycyjnego, zob. (4a) i (12a). $\mathrm{W}$ moim przekonaniu lepsze jest rozwiązanie drugie.

Warto dodać, że na płynność granic pomiędzy grupami luźnymi i ścisłymi zwraca już uwagę K. Kallas (1980: 71-72). Autorka wiąże ten problem z akomodacją przypadkową członów, co prowadzi do odróżnienia następujących realizacji:

(14) Nie miał książki „Londyńskie ABC”.

(14a) Nie miał tej ksiażki, ,Londyńskiego ABC”.

W porównywanej parze przykładów druga konstrukcja (14a) zostałaby uznana za apozycję luźną (por. Saloni 2004). W jej wypadku sygnał izolacji uniemożliwiałby narzucenie podrzędnikowi wartości mianownika. Dodajmy, że z problemem ustalania granic pomiędzy charakteryzowanymi w tym miejscu grupami wiąże się kwestia przestawialności członów takich konstrukcji, por::

(15) Miasto Toruń stynie z pierników.

(15a) ?Toruń miasto stynie z pierników.

(15b) ?Toruń - miasto - stynie z pierników.

(15c) Toruń - miasto leżace nad Wisła - stynie z pierników.

Z punktu widzenia prowadzonych tu obserwacji istotne wydają się przykłady (15b) i (15c). Brak akceptowalności zdania (15b) wynika jednak z ograniczeń semantycznych nakładanych na sposób realizacji struktury wtrąconej.

2. Znaczny zbiór wyrażeń zaliczanych do klasy wtrąceń niewłaściwych równoważnych dystrybucyjnie określonemu składnikowi struktury podstawowej i ustabilizowanych pod względem szyku jest tworzony przez człony czasownikowe. Warto przy tym zauważyć, że pod różnymi względami ciągi takie są podobne do luźnych grup apozycyjnych. Obserwacja całostek zaliczanych do tak wyodrębnionego zbioru wywołuje konieczność rozważenia dwóch problemów szczegółowych: (a) warunków użycia czasownikowego 
ciągu wtrąconego; (b) interpretacji struktur składniowych, które warunków takich nie spełniają.

2.1. Przede wszystkim komponent wtrącony może wchodzić w relację składniową bądź z formą finitywną, bądź frazą bezokolicznikową. W obu wypadkach podlega on jednak innym ograniczeniom, por.:

(16) Dlaczego mamy rozkładać (rozszerzać) parasol nad przedsiębiorstwami. (IPI)

(17) Wyszukiwarka ta zindeksowała (znalazła) ponad 7 milionów adresów $W W W$. (IPI)

(18) Korolko transkrybuje jako widali (widzieli). (IPI)

Zauważmy, że forma fleksyjna wyróżnionych wyżej komponentów nie jest dowolna, a tym samym dostrzega się istniejącą pomiędzy wtrąceniem a składnikiem ciągu głównego zależność formalną. Dodatkowo każdy z członów wydzielonych może zastępować wyrażenie antepozycyjne, choć nie może równocześnie wystąpić z nim bez znaków izolacji graficznej. Użycie czasownika $\mathrm{w}$ funkcji wtrącenia jest wobec tego warunkowane przede wszystkim powielaniem determinowanych parametrów fleksyjnych składnika kontekstowego. To spostrzeżenie jest podstawowym argumentem przemawiającym za uznaniem tezy, że pomiędzy występującym w ciągu zasadniczym czasownikiem - nazwijmy go głównym - a wtrąceniem dochodzi do transmisji wymagań składniowych.

Jeżeli ciąg wtrącony wchodzi w relację z frazą finitywną, to obligatoryjna transmisja dotyczy wartości kategorii osoby, liczby i rodzaju, pod warunkiem jednakże, że są one akomodowane w komponencie nadrzędnym. Pozostałe wartości nie podlegają determinacji, a tym samym mogą być różne w czasowniku głównym oraz wtrąconym. Inaczej jest przy identyfikacji stosunku z bezokolicznikiem, kiedy to narzucenie takiej cechy wyklucza zmienność innych parametrów. Warto dodać, że w omawianych kontekstach wartość aspektu również nie podlega determinacji, por.:

(16a) *Dlaczego mamy rozkładać (rozszerzali) parasol nad przedsiębiorstwami. 
(19) Jest prawdopodobne, że przytrutych byto (jest) jeszcze więcej. (IPI)

(20) Gdybym mógt (mogta) coś zmienić na terenie gminy i powiatu. (IPI)

(21) Każdy ma (miat) jakieś swoje racje...

Przykład (16a) potwierdza ograniczenie użycia wtrącenia przy niezachowaniu transmitowanych cech gramatycznych (tu bezokolicznika). Ciągi izolowane w (19) i (21) różnią się z kolei wartościami kategorii niepodlegających determinacji. Podobnie w (20), gdzie wartość rodzaju komponentu mógt nie jest narzucana przez żaden składnik ciągu zdaniowego. Zauważmy, że w przykładach (19)-(21) dopuszczalne jest zastąpienie komponentu antepozycyjnego ciągiem izolowanym.

2.2. Jeżeli zgodzimy się ze sformułowanymi wyżej tezami, to należy rozważyć przykłady, w których do dostrzeżonej zależności nie dochodzi, por.:

(22) Ilekroć dziś przechodzę (,,przechodzić”) z Websterem koło tej ławki $i$ widzę kogoś śpiacego w śpiworze, myślę sobie, że niekoniecznie musi być pijaczkiem. (IPI)

(23) ?Amadinda zeszła (zeszli) ze sceny. (IPI)

(24) Jeżeli zostanę (odpukać!) okradziony, wystapię o odszkodowanie... (IPI)

Przede wszystkim z nieprzestrzeganiem sformułowanej wyżej zasady transmisji mamy do czynienia wówczas, gdy komponent izolowany jest użyty w supozycji materialnej, por. (22). Bezokolicznik przechodzić stanowi odnośnik do leksemu, którego częścią jest forma fleksyjna przechodze, funkcjonuje wobec tego w tekście na innych zasadach niż wyrażenia wyodrębnione w przykładach (16)-(21). Przykład (23) z kolei należy uznać za wątpliwy, gdyż brak realizacji obligatoryjnej transmisji wartości kategorii liczby i rodzaju ze strony wyrażenia zeszła nie ma żadnego uzasadnienia formalnego. Jak można sądzić, przyczyną powstania takiej realizacji są czynniki komunikatywne. Wreszcie komponent odpukać w (24) jest wtrąceniem właściwym i wchodzi w relacje składniowe nie z czasownikowym elementem zostanę, lecz z większą strukturą syntaktyczną (zob. Moroz 2010: 264, Wajszczuk 2005: 112). 
2.3. W opozycji do wyżej scharakteryzowanych ciągów znajdują się wyrażenia, w których elementem wtrąconym może być zarówno bezokolicznik, jak i realizacja niebezokolicznikowa. W takim wypadku wtrącenie - zależnie od formy - wchodzi w stosunek składniowy albo z bezokolicznikiem, albo też z formą finitywną. W drugim wypadku możliwość zastępowania $\mathrm{z}$ reguły dotyczy całej konstrukcji $\mathrm{V}+\mathrm{INF}$, por.:

(25) Twoja kamera nie umiała odkryć (wydobyć) tej prostej zasady.

(25a) Twoja kamera nie umiała odkryć (nie wydobyta) tej prostej zasady.

(26) Inwestorzy ci będa mogli zamienić (zrolować) swoje papiery na walory. (IPI)

W obu przypadkach transmisja cech gramatycznych, o której wspominałem wyżej, wychodzi od różnych składników - bezokolicznika bądź formy finitywnej, por.

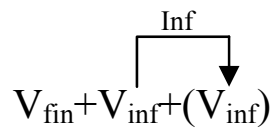

$\left(25 a^{\prime}\right)$

$$
\mathrm{V}_{\text {fin }}+\mathrm{V}_{\text {inf }}+\left(\mathrm{V}_{\text {fin }}\right)
$$

Odmienną interpretację przypisuje się natomiast konstrukcjom, w których ciąg zdaniowy jest konstytuowany przez formę czasownika niewłaściwego. Ponieważ w takim wypadku nie występuje determinacja komponentu $\mathrm{V}_{\text {fin }} \mathrm{W}$ ciągu podstawowym, nie obserwuje się transmisji parametrów fleksyjnych zgodnej ze schematem (25a'). W takich całostkach elementem wtrąconym jest $\mathrm{z}$ reguły forma bezokolicznikowa, determinowana zgodnie ze schematem (25'). Możliwa - choć prawdopodobnie gorsza - będzie realizacja tego wyrażenia przez formę czasownika niewłaściwego, por.:

(27) Mniejsze blizny można usuwać (zmniejszać) w gabinecie dermatologicznym. (IPI)

(27a) Mniejsze blizny można usuwać (trzeba) w gabinecie dermatologicznym. 
(27b) * Mniejsze blizny można usuwać (zmniejszamy) w gabinecie dermatologicznym.

2.4. Warto również zwrócić uwagę na grupę wtrąceń niewłaściwych pozostających w relacjach formalnych do antepozycyjnych ciągów zawierających wykładnik negacji - nie - bądź komponent się. Obecność takich elementów w całostce podstawowej nie determinuje struktury członu izolowanego - wyrażenia takie mogą być albo pomijane, albo też powtarzane w ciągu wtrąconym, por.:

(28) Z tych to czasów notuje on od Słowian przejęte zrzasnać się (przerazić się).

(29) Trzeba było przecież wstać, ubrać się (wystroić) i posilić. (IPI)

(30) Ten ostatni tercet nie ma (miat) sobie równych. (IPI)

(31) Jeśli zaś tak, dlaczego nie odkryła (nie wynalazła) koła cywilizacja przedkolumbijska $w$ Ameryce? (IPI)

Zauważmy, że interpretacja przypisywana komponentom izolowanym występującym w powyższych konstrukcjach może być różna. Przede wszystkim wyrażenia nawiasowe - zależnie od realizacji - są równoważne syntaktycznie ciągom o różnej charakterystyce składniowej. W przykładzie (31) wtrącenie nie wynalazła może zastępować strukturę nie odkryła, podczas gdy w zdaniu (30) jest ono równoważne jedynie formie czasownika bez wykładnika negacji miał $\equiv m a^{3}$. Warto dodać, że całostki takie zachowują się tym samym analogicznie do struktur omówionych wyżej (zob. § 2.3.), gdzie równoważność zachodziła między członem izolowanym a konstrukcją finitywno-bezokolicznikową (nie umiała odkryć $\equiv$ nie wydobyta) lub tylko formą finitywną (nie umiała $\equiv$ nie chciała).

Na marginesie podkreślmy, że konstrukcji (30) da się przypisać inną interpretację. Można mianowicie uznać, że stosunek syntaktyczny zachodzi w tym wypadku pomiędzy ciągiem zanegowanym nie ma oraz afirmatywnym miał, ale wówczas oba człony nie są sobie równoważne składniowo. Po-

3 Zachowanie takie można wiązać do pewnego stopnia z przypisywaną wtrąceniom cechą zmiennego zasięgu, por. Bogusławski (1977: 289), Grochowski (1983: 252). 
dobne cechy ma konstrukcja, w której ciąg izolowany jest strukturą zanegowaną, podczas gdy realizacja antepozycyjna - afirmatywną, por.:

(32) Członkowie spółdzielni, którzy obecnie maja spółdzielcze prawo własności, moga (nie musza) złożyć wniosek o przeksztatcenie w odrębna własność. (IPI)

Jak można zauważyć, w powyższym przykładzie dochodzi do determinacji wartości kategorii osoby oraz liczby w komponencie nie muszą. Nie może ona jednakże zastępować składnika antepozycyjnego, a tym samym nie jest równoważna mu syntaktycznie. Wynika to $\mathrm{z}$ faktu, że transmisji w powyższych konstrukcjach podlegają wybrane wartości kategorii modulujących, nie zaś selektywnych. Tym samym w sytuacji, gdy wtrącenie ma inne wymagania składniowe względem członów całostki podstawowej niż czasownik występujący w jego antepozycji, wzajemne zastępowanie nie jest możliwe, por::

(32a) *Członkowie spółdzielni [...] nie musza złożyć wniosek o przekształcenie...

Dostrzeżenie powyższej właściwości sprawia, że występującą w przykładzie (32) całostkę izolowaną należy uznać za współskładnikowe wtrącenie niewłaściwe. Wyrażenia takie bliskie są bowiem strukturom, których inicjalnym komponentem jest jednostka spajająca ${ }^{4}$. W zdaniu (32) miałaby ona jednak realizację zerową. Warto dodać, że redukcja sygnałów izolacji jest tu niemożliwa $\mathrm{z}$ uwagi na różnice $\mathrm{w}$ zakresie wymagań:

(32b) Członkowie spółdzielni, którzy obecnie maja spółdzielcze prawo własności, moga (ale nie musza) złożyć wniosek o przekształcenie w odrębna wtasność.

(32c) *Członkowie spółdzielni, którzy obecnie maja spółdzielcze prawo własności, moga, ale nie musza złożyć wniosek o przekształcenie w odrębna wtasność.

${ }^{4} \mathrm{Na}$ możliwość interpretacji apozycji dwustronnie izolowanych jako konstrukcji współrzędnych zwracała uwagę M. Gębka-Wolak (1999). 
$\mathrm{Na}$ marginesie prowadzonych obserwacji warto zasygnalizować to, że w wypadku wtrąceń na zasadę zgodności wymagań sąsiadujących członów należy spojrzeć nieco liberalniej. Jak się wydaje, komponent antepozycyjny oraz wtrącenie - zob. (32) - mogą różnić się wymaganiami składniowymi, co nie jest możliwe w odniesieniu do struktur współrzędnych (por. Buttler 1986: 439, Jadacka 2005: 163-164, Kallas 1993: 48-49).

3. Powyższe obserwacje pozwalają na przypisanie analizowanym w tym tekście strukturom kilku cech dystynktywnych. Przede wszystkim zdecydowana większość wyróżnionych przez Krystynę Kallas (1980) apozycji luźnych lokuje się w pierwszej klasie wtrąceń - ciągów równoważnych syntaktycznie komponentowi całostki podstawowej oraz ustabilizowanych pod względem szyku. Podobnie należy interpretować zbliżone do nich strukturalnie wtrącenia czasownikowe. Odstępstwa od takiej kwalifikacji są nieliczne i dotyczą głównie realizacji werbalnych zawierających wykładnik negacji, por. (33). Uznaje się je zazwyczaj za współskładnikowe wtrącenia niewłaściwe. Tym samym obie wyróżnione grupy pozostają w opozycji przede wszystkim do konstrukcji

(33) Była ogromna, świeżo wywoskowana i ozdobiona lampionami w kolorowych (,,bajecznie”) batikach. (IPI)

(34) Sama realizacja obiektu hotelowego (,,pod klucz”) potrwa 18 miesięcy. (IPI)

(35) Coś (dobrego) się stanie! (IPI)

Zastosowane w przykładach (33)-(35) znaki izolacji mają charakter fakultatywny i mogą zostać usunięte - przy ewentualnej zmianie szyku. Komponent izolowany zajmuje również w strukturze głównej niewypełnioną pozycję składniową, por.:

(33a) Byta ogromna, świeżo wywoskowana $i$ ozdobiona lampionami $w$, bajecznie” kolorowych batikach.

(35a) Coś dobrego się stanie!

5 Wtrącenia takie określane są często mianem izolowanych członów syntaktycznych, por. m.in. Saloni 1977, Świdziński 1996, Wiśniewski 1994. 
Redukcja sygnałów izolacji nie była - o czym warto pamiętać - możliwa w wypadku apozycyjnych grup luźnych, co stanowi pochodną uznania wtrąceń tego typu za wyrażenia równoważne syntaktycznie składnikowi ciągu głównego:

(25b) * Twoja kamera nie umiała odkryć wydobyć tej prostej zasady.

(6) * Trafit się pan na stanowisku buchalter z Warszawy.

Występujące w zdaniach (33)-(35) niewspółskładnikowe wtrącenia niewłaściwe różnią się także od wtrąconych grup apozycyjnych oraz analogicznych struktur czasownikowych zdecydowanie słabszymi ograniczeniami linearyzacji. Wyrażenia takie nie muszą bowiem występować w bezpośredniej postpozycji względem komponentu struktury podstawowej, z którym wchodzą w stosunki składniowe, por.:

(33b) Była [...] i ozdobiona lampionami w (,,bajecznie”) kolorowych batikach.

(34a) Sama realizacja (,,pod klucz”) obiektu hotelowego potrwa 18 miesięcy.

(35b) Coś się stanie (dobrego)!

Tym samym zasadniczą cechą dystynktywną większości apozycjnych grup luźnych oraz analizowanych tu czasownikowych wtrąceń niewłaściwych jest - jak można przypuszczać - ich postpozycyjna styczność. Odstępstwa od takiej realizacji są rzadkie i obserwowane przede wszystkim przy niezbyt długich podrzędnikach komponentu struktury podstawowej, szczególnie zaimkowych, por.:

(36) Posiadacze trzyletnich obligacji podlegajacych wykupowi w sierpniu br. mogli zamieniać je (rolować) na nowe papiery płacac 98,1 zł za każdy „,́́wieży” walor. (IPI)

4. Proponowane wyżej interpretacje zdają się potwierdzać zależność istniejącą pomiędzy obiektami wyznaczanymi przez pojęcie luźnej grupy apozycyjnej a pewnymi typami wtrąceń niewłaściwych. Z takiego spostrzeżenia wynika teza, że do opisu wielu konstrukcji apozycyjnych można wykorzy- 
stać narzędzia stosowane w charakterystyce wyrażeń wtrąconych. Działanie takie może z kolei prowadzić do uwypuklenia cech wspólnych istniejących pomiędzy konstrukcjami stanowiącymi przedmiot zainteresowania Krystyny Kallas a strukturami do nich analogicznymi.

\section{Bibliografia}

BogusŁawski A., 1977, Problems of the thematic-rhematic structure of sentences, Warszawa: PWN.

Buttler D., 1986, Składnia, w: D. Buttler, H. Kurkowska, H. Satkiewicz, Kultura języka polskiego. Zagadnienia poprawności gramatycznej, Warszawa: PWN, s. $301-448$.

GĘBKA-WolaK M., 1999, O możliwości interpretowania grup apozycyjnych z członem wyodrębnionym interpunkcyjnie jako konstrukcji współrzędnych, Poradnik Językowy, z. 1, s. 21-29.

Grochowski M., 1983, Metatekstowa interpretacja parentezy, w: T. Dobrzyńska, E. Janus (red.), Tekst $i$ zdanie, Wrocław: Ossolineum, s. 247-258.

JADACKA H., 2005, Kultura języka polskiego. Fleksja, słowotwórstwo, składnia, Warszawa: Wydawnictwo Naukowe PWN.

Kallas K., 1978, Konstrukcje apozycyjne we współczesnym języku polskim. Próba definicji terminu na podstawie charakterystyki formalno-syntaktycznej, Acta Universitatis Nicolai Copernici, z. 93, s. 3-30.

Kallas K., 1980, Grupy apozycyjne we współczesnym języku polskim, Toruń: Wydawnictwo UMK.

Kallas K., 1993, Składnia współczesnych polskich konstrukcji współrzędnych, Toruń: Wydawnictwo UMK.

Moroz A., 2010, Parenteza ze składnikiem czasownikowym we współczesnym języku polskim, Toruń: Wydawnictwo Naukowe UMK.

NSPP, 2000, Nowy słownik poprawnej polszczyzny, A. Markowski (red.), Warszawa: Wydawnictwo Naukowe PWN.

SALONi Z., 1977, W sprawie interpunkcyjnego usamodzielnienia członu zdaniowego, Język Polski LVII, z. 4, s. 261-272.

SAloni Z., 2004, O podrzędnym mianowniku przyrzeczownikowym w języku polskim, w: A. Moroz, M. Wiśniewski (red.), Studia z gramatyki i semantyki języka polskiego. Prace dedykowane Profesor Krystynie Kallas, Toruń: Wydawnictwo UMK, s. 55-66.

ŚwIDZIŃsKi M., 1996, Własności składniowe wypowiedników polskich, Warszawa: Dom Wydawniczy ELIPSA. 
Wajszczuk J., 2005, O metatekście, Warszawa: Katedra Lingwistyki Formalnej UW.

WiśnIEWSK I M., 1994, Strukturalna charakterystyka polskich wypowiedzeń niezdaniowych, Toruń: Wydawnictwo UMK.

\section{Free appositions vs. formally dependent interjections ( su m mary)}

The article proves the connection between free appositional constructions and selected classes of improper interjections. In the course of the analysis, the author has demonstrated that most of the described structures are characterized by structural closeness and postposition in relation to the connected components. The similarity between appositions and certain strings containing an interjected verb phrase has also been shown. Furthermore, such expressions fulfill the definition of an interjection. Similar formal restrictions, such as doubly isolated apposition, are imposed upon these structures. Additionally, the article discusses the rules of usage for this type of interjected verbs. 